This is a provisional PDF only. Copyedited and fully formatted version will be made available soon.

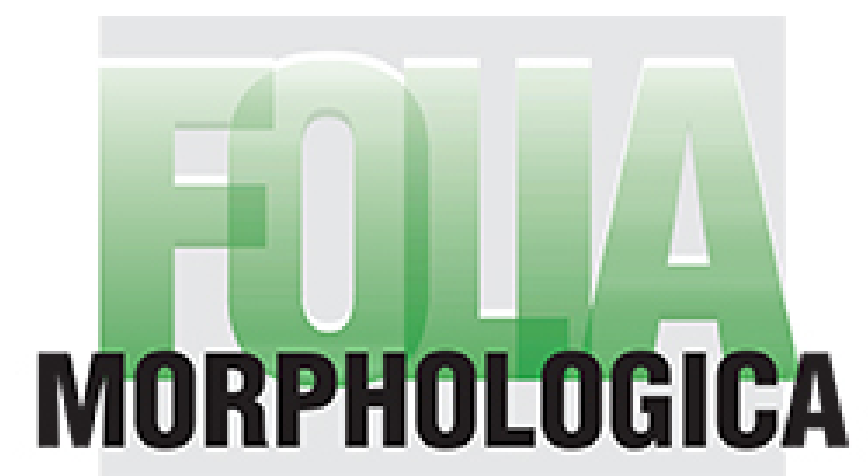

ISSN: 0015-5659

e-ISSN: $1644-3284$

\title{
The structure of the rostral epidural rete mirabile and caudal epidural rete mirabile of the domestic pig
}

Authors: S. Graczyk, M. Zdun

DOI: $10.5603 / F M . a 2022.0013$

Article type: Original article

Submitted: $2021-11-15$

Accepted: $2022-01-17$

Published online: 2022-01-31

This article has been peer reviewed and published immediately upon acceptance.

It is an open access article, which means that it can be downloaded, printed, and distributed freely, provided the work is properly cited.

Articles in "Folia Morphologica" are listed in PubMed. 


\title{
The structure of the rostral epidural rete mirabile and caudal epidural rete mirabile of the domestic pig
}

S. Graczyk, M. Zdun, Epidural rete mirabile in swine

S. Graczyk, M. Zdun

Department of Basic and Preclinical Sciences, Institute of Veterinary Medicine, Nicolaus Copernicus University in Torun, Poland

Address for correspondence: Szymon Graczyk, Department of Basic and Preclinical Sciences Institute of Veterinary Medicine, Nicolaus Copernicus University in Torun, ul. Lwowska 1, 87-100 Toruń, Poland, e-mail: graczyk72@gmail.com

\begin{abstract}
The rostral epidural rete mirabile in the domestic pig has been studied by many scientists, however, the caudal epidural rete mirabile has been poorly understood and is rarely mentioned in the literature in domestic pig species. Based on the role of the rostral epidural rete mirabile in retrograde transfer of neurotransmitters and its localization and structure, we hypothesize that the caudal rete may also play an important role in this process. The study was conducted on 80 domestic pigs (Sus scrofa domestica) of the Suidae family, including 60 piglets aged 0-20 days and 20 adult animals aged 5-9 months. The rostral epidural rete mirabile is an even well-developed structure consisting of dozens of anastomosing arterioles embedded in the cavernous sinus, formed by the maxillary and external ocular artery branches, which are extensions of the external carotid artery, and a thick branch to the rostral epidural rete mirabile. However, the caudal epidural rete mirabile is a structure made up of several interlacing arterioles consisting of the vertebral, condylar and occipital arteries on the caudal side, while on the rostral side it is made up of the middle meningeal artery branching off the inner surface of the temporal bone. The whole caudal epidural rete mirabile is embedded in the basilar and occipital sinuses, which led us to hypothesise that in these
\end{abstract}


sinuses a retrograde transfer of neurotransmitters may take place analogous to the rostral epidural rete mirabile.

Key words: cavernous sinus, swine, retrograde transfer of neurotransmitters, rete mirabele

\section{INTRODUCTION}

The rostral epidural rete mirabile (rete mirabele epidurale rostrale) and the caudal epidural rete mirabile (rete mirabele epidurale caudale) are the main sources of arterial blood supplied to the encephalon of the domestic pig. The presence of both retia in this species was mentioned by $[5,14,45]$, but the researchers did not describe their structure in detail. The available studies (publications) provide information about the location of both retia and their general characteristics [6, 23, 31, 50]. The structure of the rostral epidural rete mirabile is closely related to its function. It plays an important role in selective cooling of the brain [3, 19, 43], the water-saving mechanism in the body [20] and in the retrograde transfer of neurotransmitters [27, 28]. However, there have been no studies on the function of the caudal epidural rete mirabile. This study provides an analysis of the location of both retia, their structure and relations with the venous system. The aim of the study was to pose hypotheses about the potential role of the caudal epidural rete mirabile and to provide information which may be used in future physiological research in this area.

\section{MATERIALS AND METHODS}

The study was conducted on 80 domestic pigs (Sus scrofa domestica) of the Suidae family, including 60 piglets aged 0-20 days and 20 adult animals aged 5-9 months. All the animals were provided by private breeders.

25 (21 piglets, 4 adults) specimens were prepared by injecting red self-curing DURACRYL ${ }^{\circledR}$ PLUS (SpofaDental) into the bilateral common carotid arteries. Blue DURACRYL ${ }^{\circledR}$ PLUS was also injected into the venous system of 15 (13 piglets, 2 
adult) specimens, i.e. into the venous sinus of the eye. 15 piglets was injected only by blue DURACRYL ${ }^{\circledR}$ PLUS into the venous sinus of the eye. When the specimens had cured after about 20 minutes, the material was enzymatically macerated with Persil powder (Henkel) at $42{ }^{\circ} \mathrm{C}$ for about one month. The procedure resulted in corrosion casts of blood vessels on the bone scaffold. The remaining 25 (15 piglets, 10 adults) specimens were prepared by injecting liquid red LBS 3060 latex into the bilateral common arteries. Blue LBS 3060 latex was also injected into the external jugular vein of 15 (11 piglets, 4 adults) specimens. In addition, 15 piglets were only injected with blue LBS 3060 latex into the external jugular vein. Next, the material was immersed in a $5 \%$ formalin solution for 14 days to harden. Then the arteries were dissected with surgical instruments to obtain images of the blood vessels on the animals' tissues. The names of the anatomical structures were standardised according to the Nomina Anatomica Veterinaria (2017).

\section{Ethics approval}

All applicable international, national, and institutional guidelines for the care and use of animals were followed.

\section{RESULTS}

The rostral epidural rete mirabile of the domestic pig is mainly formed by the ramus to the rostral epidural rete mirabile (ramus ad rete mirabele epidurale rostrale), which is an extension of the internal carotid artery (arteria carotis interna). Blood is also supplied to the rete by arteries, which are an extension of the external carotid artery (arteria carotis externa). This is the maxillary artery (arteria maxillaris) through its rami to the rostral epidural rete mirabile, which is formed by two vessels merging just before the rete. Apart from that, the maxillary artery branches into the external ophthalmic artery (arteria opthalmica externa), whose rami go to the rostral epidural rete mirabile. The rami to the rostral epidural rete mirabile extending from the maxillary and external ophthalmic arteries do not play a significant role in supplying arterial blood to the encephalon because their lumens are too small. The intracranial segment of the 
internal carotid artery emerges from the rostral epidural rete mirabile. It contributes to the formation of the cerebral arterial circle (circulus arteriosus cerebri) in the form of paired rostral cerebral arteries (arteriae cerebri rostrales) and paired caudal communicating arteries (arteriae communicans caudales).

The rostral epidural rete mirabile is a well-developed, paired structure composed of numerous tiny anastomosing arteries. It enters the cranial cavity through the foramen lacerum and bends at its rostral edge. The intracranial part comprises $60 \%$ of the rete, whereas the extracranial part comprises $40 \%$. Due to the course of the arteries the rostral epidural rete mirabile is shaped like an inverted saddle placed on the basisphenoid bone (Fig 1). In a cross-sectional view the rostral epidural rete mirabile has a circular outline. All arteries in the rete were of the same thickness. Their number varied depending on the age of the animal. On average, the piglets had 103 arteries in the left rete, with a standard deviation of 18, and 120 arteries in the right rete, with a standard deviation of 20. The adult animals had on average 132 vessels in the left rete, with a standard deviation of 20, and in 147 vessels in the right rete with a standard deviation of 19. The cross section of this rete showed that newborn piglets had one vessel with a much larger diameter than the other vessels in the rete. However, this feature disappeared shortly after birth. The bilateral retia were connected by 35-40 small arterioles in the anterior segment, regardless of the age of the animal. As for the length of the rete in piglets, its average was $9.45 \mathrm{~mm}$ with a standard deviation of $3.65 \mathrm{~mm}$. The same value in adults was $24.51 \mathrm{~mm}$ with a standard deviation of $2.08 \mathrm{~mm}$. The diameters of the arterioles present in the rete in both study groups were also measured. In the piglet group, the mean value of the arterioles diameter of the rete was $0.26 \mathrm{~mm}$ with a standard deviation of 0.03 . In the adult pig group, this size was equal to $0.45 \mathrm{~mm}$ with a standard deviation of $0.05 \mathrm{~mm}$.

The posterior side of the caudal epidural rete mirabile is formed by the vertebral artery (arteria vertebralis), which is joined by the occipital artery (arteria occipitalis) before the rete. The posterior side of the rete is also formed by the condylar artery, which reaches the rete through the foramen alare of the atlas (Fig 2). Meningeal branch (ramus meningeus) of the condylar artery is another tributary to the rete on the rostral side. It branches into 6-8 arterioles running dorsally in a triangular shape along the inner surface of the lateral part of the occipital bone. Next, these arterioles extend to supply 
blood to the meninges. The caudal epidural rete mirabile is connected to the cerebral arterial circle through the basilar artery (arteria basillaris), which is formed by the bilateral vertebral arteries.

The caudal part of the rete is situated on the border of the atlas and the occipital bone, just before the entrance to the foramen magnum, whereas the rostral part adjoins the inner surface of the lateral part of the occipital bone. It is a flat structure, extending on one plane. The number of arteries in the rete does not change during ontogenesis. However, the course of the arterioles supplying blood to the meninges, i.e. the rostral part of the rete, changes with the age of the animal. The arterial vessels run straight in young animals, but their course becomes more tortuous as animals grow older. There was no direct connection between the rostral and caudal epidural retia mirabilia.

The cavernous sinus enters the cranial cavity through the foramen lacerum and fills most of it. It is seated on the presphenoid bone just below the surface of the meninges. In the central part of this sinus there is a fragment connecting the bilateral sinuses. It is the intercavernous sinus (sinus intercavernosus), situated rostrally from the sella turcica. The rostral segment of the caudal epidural rete mirabile with the meningeal branch from the condylar artery is completely covered by the occipital sinus, which extends over the entire inner surface of the lateral part of the occipital bone. This sinus is in direct contact with the basilar sinus, which is an extension of the cavernous sinus in the caudal direction. It runs along the border between the basisphenoid bone and the petrous part of the temporal bone up to the inner surface of the alae of the atlas, where it extends into the ventral vertebral venous plexus, which runs on both sides of the spinal canal. Apart from that, at the caudal fragment of the rete, i.e. on the border between the foramen magnum and the vertebral foramen of the atlas, a segment connecting the bilateral basilar sinuses, i.e. the interbasilar sinus (sinus interbasilaris), was found. The cavernous sinus together with the basilar and occipital sinuses form a system which completely covers the rostral and caudal retia (Fig 3). The material from the arterial system was not mixed with the material injected into the veins. This fact shows that the blood returning from the cephalic region does not mix with the oxygenated blood from the lungs. A intracranial segment of the internal carotid artery emerges from the rostral epidural rete mirabile embedded in the cavernous sinus and forms the cerebral arterial circle. Part of the occipital sinus surrounds numerous meningeal arteries supplying 
arterial blood to the meninges, whereas the basilar sinus surrounds the bilateral vertebral arteries, which contribute to the formation of the basilar artery.

\section{DISCUSSION}

A paired epidural rete mirabile can be found not only in the domestic pig but also in other even-toed ungulates of the Atriodactyla order, i.e. Antilopinae [11], Moschidae [10], Bovinae [7, 13, 37, 47], Giraffidae [15, 33], Caprinae [1, 38], Camelidae [22, 34, 47] Cervidae [25, 51], and Antilocapridae [4]. The only exception is mouse-deer of the Tragulidae family, which do not have a rostral epidural rete mirabile. The components of their cerebral arterial circle are formed by the internal carotid artery [9, 32]. The rostral epidural rete mirabile in animals of the Bovidae family is formed by the rostral branches and the caudal ramus to the rostral epidural rete mirabile $(51,52)$. Apart from the aforementioned tributaries, blood to the rete is also supplied by the condylar artery, which is characteristic of the Cervidae and Giraffidae families [12, 16, 26]. Kieltycka-Kurc et al. [26] observed that the rostral epidural rete mirabile in animals of the Camelidae family was formed by branches running from the maxillary artery and the external ophthalmic artery. The internal carotid artery is the third tributary, which becomes obliterated during the ontogenesis of animals of the Suidae family [15, 49].

The caudal epidural rete mirabile can also be found in animals of the Bovini tribe, where it is an extension of the condylar artery. In contrast to animals of the Suidae family, the caudal epidural rete mirabile in representatives of the Bovini tribe is directly connected to the rostral epidural rete mirabile and it is not a paired structure [52].

Simoens et al. [38] distinguished two types of the rostral epidural rete mirabile, i.e. the fascicular type, with the intraretial segment of the internal carotid artery, which has a much greater lumen than other arterioles, this situation is observed in newborn piglets, and the bipolar type, where all vessels in the rete have similar diameters, which can be seen in a cross-sectional view. The change in rete type from fascicular to bipolar occurs shortly after birth.

The physiology of the epidural rete mirabile seems to significantly affect the regulation of the processes taking place in the body. For centuries this structure has been 
researched by scientists specialising in anatomy and physiology. Apart from the mechanisms of selective cooling of the brain, which have already been investigated [19], the retrograde transfer of neurotransmitters in the rete also seems to be very important.

Krzymowski et al. [27] were the first to describe the phenomenon of neuropeptide exchange (Lh-Rh, progesterone, and $\beta$-endorphin) in the cavernous sinus and the rostral epidural rete mirabile. This process is possible due to the specific structure of the entire complex of the rete and the cavernous sinus. The rete vessels and the sinus have a common adventitia, which ensures a direct connection, whereas the lamina muscularis mucosae of the arterial vessels in the rete itself has 3-5 layers [24]. Additionally, the arterial vessels of the rete exhibit fenestrations [23], whose diameters change depending on the phase of the cycle. This fact may be of key importance in the retrograde exchange of hormones between the venous blood returning to the sinus from the brain, pituitary gland, part of the ear and the eye, and the arterial blood in the rete. Krzymowski et al. [29] found the following cranial nerves in the cavernous sinus: the oculomotor nerve (III), trochlear nerve (IV), branches of the trigeminal nerve (V), i.e. the optic nerve $\left(\mathrm{V}_{1}\right)$ and maxillary nerve $\left(\mathrm{V}_{2}\right)$, and the abducens nerve (VI) between the arterial vessels of the rete. However, the potential role of the nerves passing through the cavernous sinus has not been investigated yet. Grzegorzewski et al. $[17,18]$ conducted a study on 37 sows' heads, in which they observed that when radiolabelled oxytocin and gonadoliberin were injected into the angular vein of the eye, there was countercurrent exchange of this hormone in the cavernous sinus exactly two days after ovulation, and then also between the $12^{\text {th }}$ and $14^{\text {th }}$ day of the cycle, in the late luteal phase. The authors of later studies observed a positive reaction after the injection of labelled dopamine in sheep [41] or testosterone and androstenol in isolated sows' heads [39, 44]. There was no evidence of the countercurrent exchange of prolactin (PRL) and luteinising hormone (LH), most likely due to the mass of these substances, i.e. 23kDa (PRL) and 30kDa $(\mathrm{LH})$. These values were greater than the mass of the aforementioned hormones, which ranged from $0.19 \mathrm{kDa}$ to $3.4 \mathrm{kDa}$ [40]. Oren [35] indicated a very important function of carbon monoxide (CO), which is synthesised on the retina thanks to the action of light rays in the phototransduction mechanism. According to the researcher, carbon monoxide may regulate the activity of various areas of the brain, thanks to the countercurrent 
exchange mechanism through the blood flowing from the ophthalmic region, including the retina, to the cavernous sinus and the exchange of this substance from the venous blood into the arterial blood of the rete. Koziorowski et al. [30] confirmed Oren's hypothesis. They also found carbon monoxide in the suprachiasmatic nucleus and suggested that it may change the expression of the per and cry genes, which regulate the circadian and seasonal rhythms, and thus it may significantly affect the daily activity of these animals. The presence of carbon monoxide synthesised on the retina, as well as the presence of the aforementioned neurotransmitters in various areas of the brain, indicates the superior function of these substances in the regulation of processes occurring in the bodies of animals and humans, and points to the existence of an internal self-regulation system [28].

As far as the caudal epidural rete mirabile is concerned, the key role seems to be played by the effect of one of the estrogens, i.e. 17- $\beta$-estradiol, which by means of the mechanism of countercurrent exchange can get from the blood returning from the brain to the vessels of this rete and reciprocally affect the cerebellum through the basilar artery. This hormone, after penetrating the cell membrane, binds to specific ER- $\alpha$ and ER- $\beta$ receptors, which, after binding to appropriate ligands, form dimers and in the form of estrogen response elements (ERE) bind to promoters for estrogen genes, finally leading to modifications in the transcription of a specific gene [8]. Apart from the fact that oestradiol has been recognised as an important regulator in the physiology of reproduction through its influence on the hypothalamic-pituitary-ovarian system, there is another, crucial function of this hormone, which is its participation in the development of the central nervous system, and particularly in the formation of motor and cognitive functions [2, 21]. In the same study [21], demonstrated high levels of ER$\beta$ receptors, during the early growth of granule cell axons and dendrites of cerebellar Purkinje cells. Expression of these receptors remained high during the growth and development of Purkinje cell dendrites and continued into adulthood. In later adulthood, high levels for ER- $\beta$ receptors were also shown in basket cells, stellate cells as well as glial cells, suggesting that these receptors may contribute significantly to cerebellar cell development and their synaptic connections. [36] in a study performed in rats demonstrated a close relationship between prostaglandin E2, which activates estradiol for aromatase synthesis, and microglia cells, which have phagocytic properties during 
cerebellar maturation. When inhibitors for estradiol and PGE2 were used, the levels of phagocytic microglia cells in the cerebellar vermis and both cerebellar hemispheres were measured using the universal marker Iba1. After aromatase inhibition, a slight decrease in phagocytic cells was demonstrated in the cerebellar vermis, while no significant change in the number of these cells was observed in the cerebellar hemispheres. However, the authors of the text emphasised that when the animal was treated exogenously, estradiol and PGE2 had little effect on the activity and number of phagocytic cells of microglia, whereas the same substances of endogenous origin were crucial for this process and were essential for its proper functioning. The reason could be the maximum threshold of these substances in the cerebellum, which was already reached by those of endogenous origin. Thus, in view of the above facts, we believe that in the area of the occipital sinus there may be an exchange of these substances between the venous blood returning from the head and the arterial blood of the caudal epidural rete mirabile, and thus the maintenance of a constant level of them in the area of the maturing cerebellum which contributes into its correct development.

These mechanisms may significantly affect the processes taking place in the animal's body, especially those occurring in the reproductive system, diseases, development and the oestrus cycle. Detailed analysis, knowledge, understanding, and skilful use of the principle of operation of this system will improve the productivity of animals and enable economical management of the herd by minimising reproductive losses. It is likely that these phenomena may play an even greater role in domestic pigs, because the paired caudal epidural rete mirabile is completely embedded in the occipital and basilar sinuses. In consequence, the process of penetration can only be improved and the amount of these substances returning to the brain can be multiplied. By demonstrating the precise relationship between the caudal epidural rete mirabile and the occipital and basilar sinuses, we believe that this study will form the basis for further research into the retrograde transfer of neurotransmitters within the caudal epidural rete mirabile, similar to the rostral epidural rete mirabile.

\section{CONCLUSIONS}


1. The rostral epidural rete mirabile is a paired structure composed of small embedded anastomosing arteries, located on the rostral edge of the foramen ovale and shaped like an inverted saddle.

2. The caudal epidural rete mirabile is a paired structure composed of the caudal and rostral parts. The caudal part, which includes the condylar, vertebral, and occipital arteries, is located on the border between the alae of the apical vertebra and the occipital bone. The rostral part, which is directly connected with the caudal part, is located on the inner surface of the lateral part of the occipital bone, which extends into the meningeal arteries.

3. The rostral epidural rete mirabile is embedded in the cavernous sinus. Both parts of the caudal epidural rete mirabile are embedded in the occipital sinus.

4. There was no direct connection between the rostral and caudal epidural retia mirabilia.

5. The number of arteries in the rostral epidural rete mirabile increases with the age of the animal.

Conflict of interest: None declared

\section{REFERENCES}

1. Alsafy MA, Kamal B, Elgendy SA. Morphological Configuration of the Brain Arterial Supply of the Goat (Capra hircus). J Appl Biol. 2017; 11:39-43.

2. Beyer C. Estrogen and the developing mammalian brain. Anat Embryol. 1999; 199:379-390, https://doi.org/10.1007/s004290050236.

3. Caputa M. The mechanisms of brain protection against overheating in human and some other species of mammals. Disseration, Uniwersytet Mikołaja Kopernika, Toruń. 1982.

4. Carlton $\mathrm{C}$, McKean T. The carotid and orbital retia of the pronghorn, deer and elk. Anat Rec. 1977; 189:91-107, https://doi.org/10.1002/ar.1091890107.

5. Daniel PM, Dawes JDK, Prichard MML. Studies of the Carotid Rete and Its Associated Arteries. Philos Trans R Soc Lond B Biol Sci. 1953; 237:173-208, https://doi.org/10.1098/rstb.1953.0003.

6. de Lima EMM, Severino RS, Carneiro FO, Drummond SS, Bombonato PP, Campos DB, Rodrigues GS. Artérias da base do encéfalo em suínos da linhagem Camborough 22. J Biosci. 2005; 21:137-147.

7. Ding Y, Shao B, Wang J. The arterial supply to the brain of the yak (Bos grunniens). Ann Anat. 2007; 189:31-38, https://doi.org/10.1016/j.aanat.2006.07.011. 
8. Edwards DP. The role of coactivators and corepressors in the biology and mechanism of action of steroid hormone receptors. J Mammary Gland Biol. 2000; 5:307-324, https://doi.org/10.1023/A:1009503029176.

9. Fukuta K, Kudo H, Sasaki M, Kimura J, Ismail D, Endo H. Absence of carotid rete mirabile in small tropic ruminants: Implications for the evolution of the arterial system in artiodactyls. J Anat. 2007; 1:112-116, https://doi.org/10.1111/j.14697580.2006.00667.x.

10. Frąckowiak H. Magistrale tętnicze głowy u niektórych rzędów ssaków. Rocz AR. 2003; 336:5-80.

11. Frąckowiak H, Dębiński D, Komosa M, Zdun M. The arterial circle of the brain, its branches and connections in selected representatives of the Antiolopinae. $\mathrm{J}$ Morphol. 2015; 276:766-771, https://doi.org/10.1002/jmor.20377.

12. Frąckowiak H, Jakubowski H. Arterial Vascularization in the Giraffe Brain. Ann Zool Fenn. 2008; 45:353-359, https://doi.org/10.5735/086.045.0418.

13. Frąckowiak H, Zdun M, Kowalczyk K, Komosa M, Kiełtyka-Kurc A. Comparison of cerebral base arteries in antelopes of Tragelaphus, Taurotragus and Boselaphus genera. Zoomorphology. 2014; 133:351-357, https://doi,org/10.1007/s00435-0140229-4.

14. Getty R, Sisson S. Sisson and Grossman's the Anatomy of the Domestic Animals. Saunders, Philadelphia 1975.

15. Godynicki S, Frąckowiak H. Arterial branches supplying the rostral and caudal retia mirabilia in Artiodactyls. Folia Morphol Warsz. 1979; 4:505-510.

16. Graczyk S, Zdun M. The structure of the rostral epidural rete mirabile in selected representatives of the Cervidae and Bovidae families. Acta Zool. 2021; 102:496501, https://doi.org/10.1111/azo.12391.

17. Grzegorzewski W, Skipor J, Wasowska B, Krzymowski T. Counter Current Transfer of Oxytocin from the Venous Blood of the Perihypophyseal Cavernous Sinus to the Arterial Blood of Carotid Rete Supplying the Hypophysis and Brain Depends on the Phase of the Estrous Cycle in Pigs. Biol Reprod. 1995; 52:139-144, https://doi.org/10.1095/biolreprod52.1.139.

18. Grzegorzewski WJ, Skipor J, Wasowska B, Krzymowski T. Counter current transfer of 125I-LHRH in the perihypophyseal cavernous sinus-carotid rete vascular complex, demonstrated on isolated pig heads perfused with autologous blood. Domest Anim Endocrinol. 1997; 14:149-160, https://doi.org/10.1016/s07397240(97)00004-0.

19. Hayward JN, Baker MA. A comparative study of the role of the cerebral arterial blood in the regulation of brain temperature in five mammals. Brain res. 1969; 16:417-440, https://doi.org/10.1016/0006-8993(69)90236-4.

20. Hetem RS, Strauss WM, Fick LG, Maloney SK, Meyer LC, Fuller A, Shobrak M, Mitchell D. Selective brain cooling in Arabian oryx (Oryx leucoryx): a physiological mechanism for coping with aridity?. J Exp Biol. 2012; 215:39173924, https://doi.org/10.1242/jeb.074666.

21. Jakab RL, Wong JK, Belcher SM. Estrogen receptor $\alpha$ immunoreactivity in differentiating cells of the developing rat cerebellum. J Comp Neurol. 2001; 430:396-409, https://doi.org/10.1002/1096-9861(20010212)430:3\%3C396::AIDCNE1039\%3E3.0.CO;2-0. 
22. Jerbi H, Khaldi S, Pérez W. Morphometric Study of the Rostral Epidural Rete Mirabile in the Dromedary (Camelus dromedarius, Linnaeus 1758). Int J Morphol. 2016; 34:1429-1435.

23. Khamas WA, Ghoshal NG. Gross and scanning electron microscopy of the carotid rete-cavernous sinus complex of the sheep (Ovis aries). Anat Anz. 1985; 159:173179.

24. Khamas WA, Ghoshal NG, Bal HS. Histomorphologic structure of the carotid rete cavernous sinus complex and its functional importance in sheep (Ovis aries). Am J Vet Res. 1984; 45:156-158.

25. Kiełtyka-Kurc A, Frąckowiak H, Brudnicki W. The Arteries of Brain Base in Species of the Cervid Family. Anat Rec. 2015; 298:735-740, https://doi.org/10.1002/ar.23096.

26. Kiełtyka-Kurc A, Frąckowiak H, Zdun M, Nabzdyk M, Kowalczyk K, Tołkacz M. The arteries on the base of the brain in the camelids (Camelidae). Ital J Zool. 2014; 81:215-220, https://doi.org/10.1080/11250003.2014.901428.

27. Krzymowski T, Skipor J, Grzegorzewski W. Cavernous sinus and carotid rete of sheep and sows as a possible place for countercurrent exchange of some neuropeptides and steroid hormones. Anim Reprod Sci. 1992; 29:225-240, https://doi.org/10.1016/0378-4320(92)90036-d.

28. Krzymowski T, Stefanczyk-Krzymowska S. Localretrograde and destination transfer of physiologicalregulators as an important regulatory system and its role.Facts and hypothesis. J Physiol Pharmacol. 2012; 63:3-16.

29. Krzymowski T, Stefańczyk-Krzymowska S, Muszak J, Gilun P, Koziorowski M. Cavernous sinus and its mysterious physiologicalfunctions: facts and hypotheses. Acta Biol Crac ser Zool. 2014; 55-56:7-15.

30. Koziorowski M, Stefańczyk-Krzymowska S, Tabęcka-Łonczyńska A, Gilun P, Kamiński MA. The gaseous messenger carbon monoxide is released from the eye into the ophthalmic venous blood depending on the intensity of sunlight. J Biol Regul Homeost Agents. 2012; 26:111-118.

31. McGrath P. Observations on the intra-cranial carotid rete and the hypophysis in the mature female pig and sheep. J Anat. 1977; 124:689-699.

32. O’Brien H. Cranial arterial pattern of the Sri Lankan spotted chevrotain, Moschiola memmina, and comparative basicranial osteology of the Tragulidae. Peer J e1451. 2015, https://doi.org/10.7717/peerj.1451.

33. O’Brien HD, Gignac PM, Hieronymus TL, Witmer LM. A comparison of postnatal arterial patterns in a growth series of giraffe (Artiodactyla: Giraffa camelopardalis). Peer J e1696. 2016, https://doi.org/10.7717/peerj.1696.

34. Ocal MK, Erden H, Ogut I, Kara ME. A quantitative study on the retial arteries in one-humped camels. Ann Anat. 1998; 18:369-371, https://doi.org/10.1016/s09409602(98)80046-0.

35. Oren DA. Humoral Phototransduction: Blood Is a Messenger. Neuroscientist. 1996; 2:207-210, https://doi.org/10.1177/107385849600200408.

36. Perez-Pouchoulen M, Yu SJ, Roby CR, Bonsavage N, McCarthy MM. Regulatory Control of Microglial Phagocytosis by Estradiol and Prostaglandin E2 in the Developing Rat Cerebellum. Cerebellum. 2019; 18:882-895, https://doi.org/10.1007/s12311-019-01071-z. 
37. Rao KT, Dayalu K, Puttannaiyah GB. A comparison of the circulus arteriosus of Bos indicus and Bos bubalis. Mysore J Agric Sci. 1968; 2:35-37.

38. Simoens P, Lauwers H, De Geest JP, De Schaepdrijver L. Functional morphology of the cranial retia mirabilia in the domestic mammals. Schweiz Arch Tierheilkd. 1987; 129:295-307.

39. Skipor J, Grzegorzewski W, Krzymowski T, Einer-Jensen N. Local transport of testosterone from the nasal mucosa tothe carotid blood and the brain in the pig. Pol J Vet Sci. 2000; 3:19-22.

40. Skipor J, Grzegorzewski W, Wasowska B, Krzymowski T. Luteinizing hormone and prolactin are not retrogradetransferred in perihypophyseal vascular complex in ewes. Reprod Biol. 2004; 4:195-201.

41. Skipor J, Wasowska B, Grzegorzewski W, Zezula-Szpyra A, StefanczykKrzymowska S, Thiery JC. Transfer of dopamineby counter-current mechanism in the ewes changes with endocrine stage. Biog Amines. 2001; 16:431-445.

42. Strauss WM, Hetem RS, Mitchell D, Maloney SK, Meyer LC, Fuller A. Selective brain cooling reduces water turnover in dehydrated sheep. PloSOne Sustain Transform. 2015; 10(2), https://doi.org/10.1371/journal.pone.0115514.

43. Strauss WM, Hetem RS, Mitchell D, Maloney SK, O'Brien HD, Meyer LC, Fuller A. Body water conservation through selective brain cooling by the carotid rete: a physiological feature for surviving climate change? Conserv Physiol. 2017; 5(1), https://doi.org/10.1093/conphys/cow078.

44. Stefanczyk-Krzymowska S, Krzymowski T, GrzegorzewskiW, Wasowska B, Skipor J. Humoral pathway for local transfer of the priming pheromone androstenol from the nasal cavity to the brain and hypophysis in anaesthetized gilts. Exp Physiol. 2000; 85:801-809, https://doi.org/10.1111/j.1469-445x.2000.02056.x.

45. Tandler, J., Uber Ein Corpus Cavernosum Tympanicum Beim Seehnnd, Monatschr. 1899; 33:437-440.

46. Taylor CR, Lyman CP. Heat storage in running antelopes: independence of brain and body temperatures. American. Am J Physiol. 1972; 222:114-117, https://doi.org/10.1152/ajplegacy.1972.222.1.114.

47. Wang XR, Liu Y, Zang LP, Wang XJ, Wu JP. Comparative anatomical study of the epidural retia mirabile in the yak and cattle. Asian J Anim Vet Adv. 2012; 7:884890, https://doi.org/10.3923/ajava.2012.884.890.

48. Weihua W. The carotid rete of the camel (Bactrianus Camelus). Chin J Anim Vet Sci. 1989.

49. WIBLE JR. The ontogeny and phylogeny of the mammalian cranial arterial pattern (internal carotid artery). Doctoral dissertation, Duke University. 1984.

50. Yaoxing C, Weizhou L, Zixu W, Kedao T, Jingliang. The morphological study on the epidural rete mirabile of the miniature swine. 1994.

51. Zdun M, Frąckowiak H. Specyfika zaopatrzenia w krew mózgowia przeżuwaczy. Med Wet. 2019; 75:389-393.

52. Zdun M, Frąckowiak H, Kiełtyka-Kurc A, Kowalczyk K, Nabzdyk M, Timm A. The Arteries of Brain Base in Species of Bovini Tribe. Anat Rec. 2013; 296:16771682, https://doi.org/10.1002/ar.22784.

53. Zdun M, Jabłoński R, Dębiński D, Frąckowiak H. The Eurasian Elk’s (Alces alces) Brain Base Arteries in View of Vascular Variation. Anat Rec. 2018; 302:339-345, https://doi.org/10.1002/ar.23968. 
Figure 1. Domestic pig (Sus scrofa domestica). Rostral epidural rete mirabile (lateral view). Dashed line - entry point to the cranial cavity. Corrosive preparation.

Figure 2. Domestic pig (Sus scrofa domestica). Caudal epidural rete mirabile posterior side (dorsal view); 1 — vertebral artery; 1' - extension of vertebral artery; 2 — conydlar artery; 3 — occipital artery; 4 — caudal epidural rete mirabile. Latex preparation.

Figure 3. Domestic pig (Sus scrofa domestica); 1 - cavernous sinus; 2 - basilar sinus; 3 - occipital sinus; 4 - interbasilar sinus. Corrosive preparation.

Figure 4. Domestic pig (Sus scrofa domestica). Relationships of the arterioles of the rostral epidural rete mirabile to the cavernous sinus. Cross-section. Corrosive preparation.

Figure 5. Domestic pig (Sus scrofa domestica); 1 - rostral part of caudal epidural rete mirabile (excised section of the occipital sinus to show the rete arterioles); 2 - occipital sinus; 3 - vertebral artery; 4 - caudal part of caudal epidural rete mirabile. Corrosive preparation. 


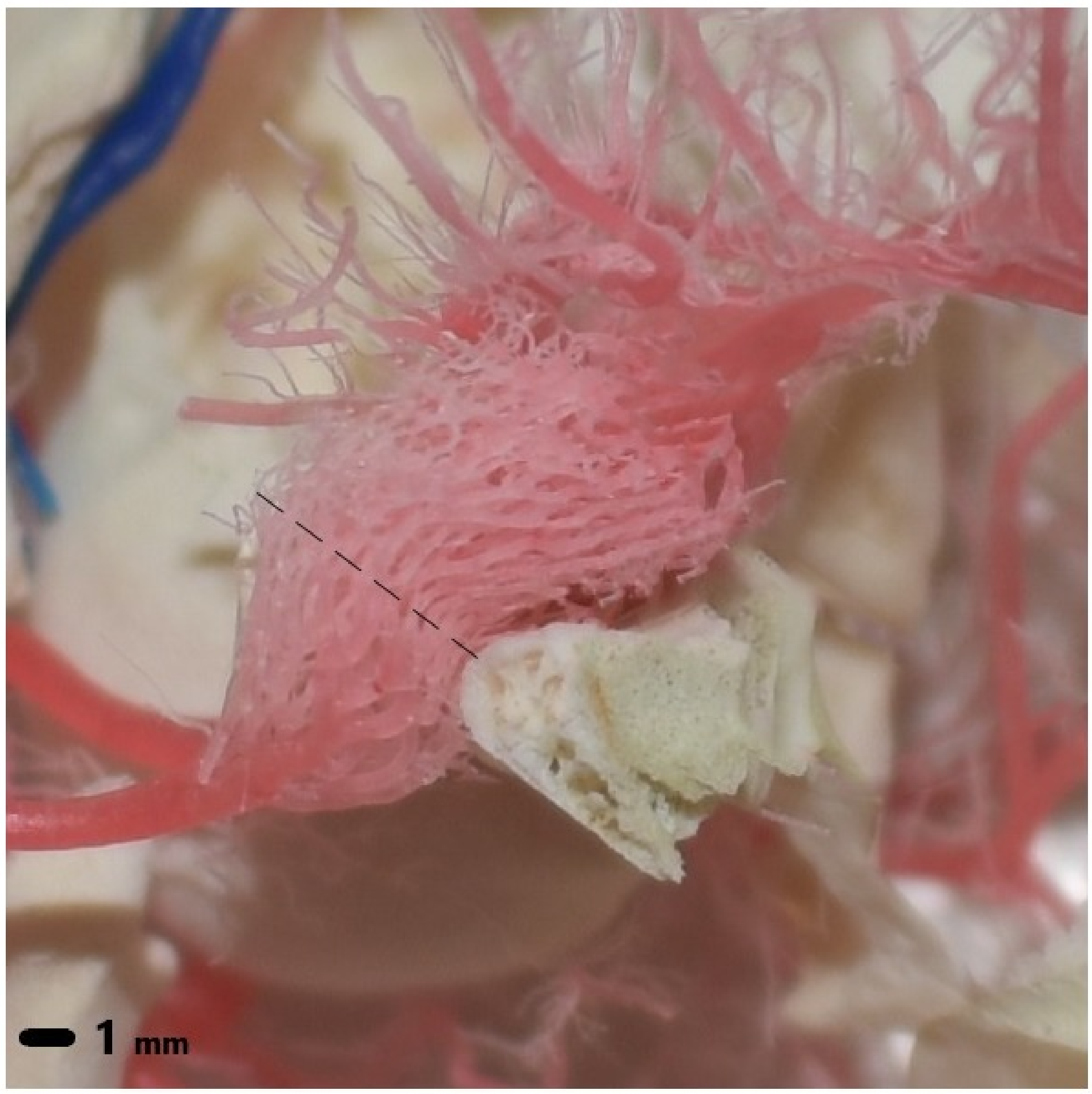




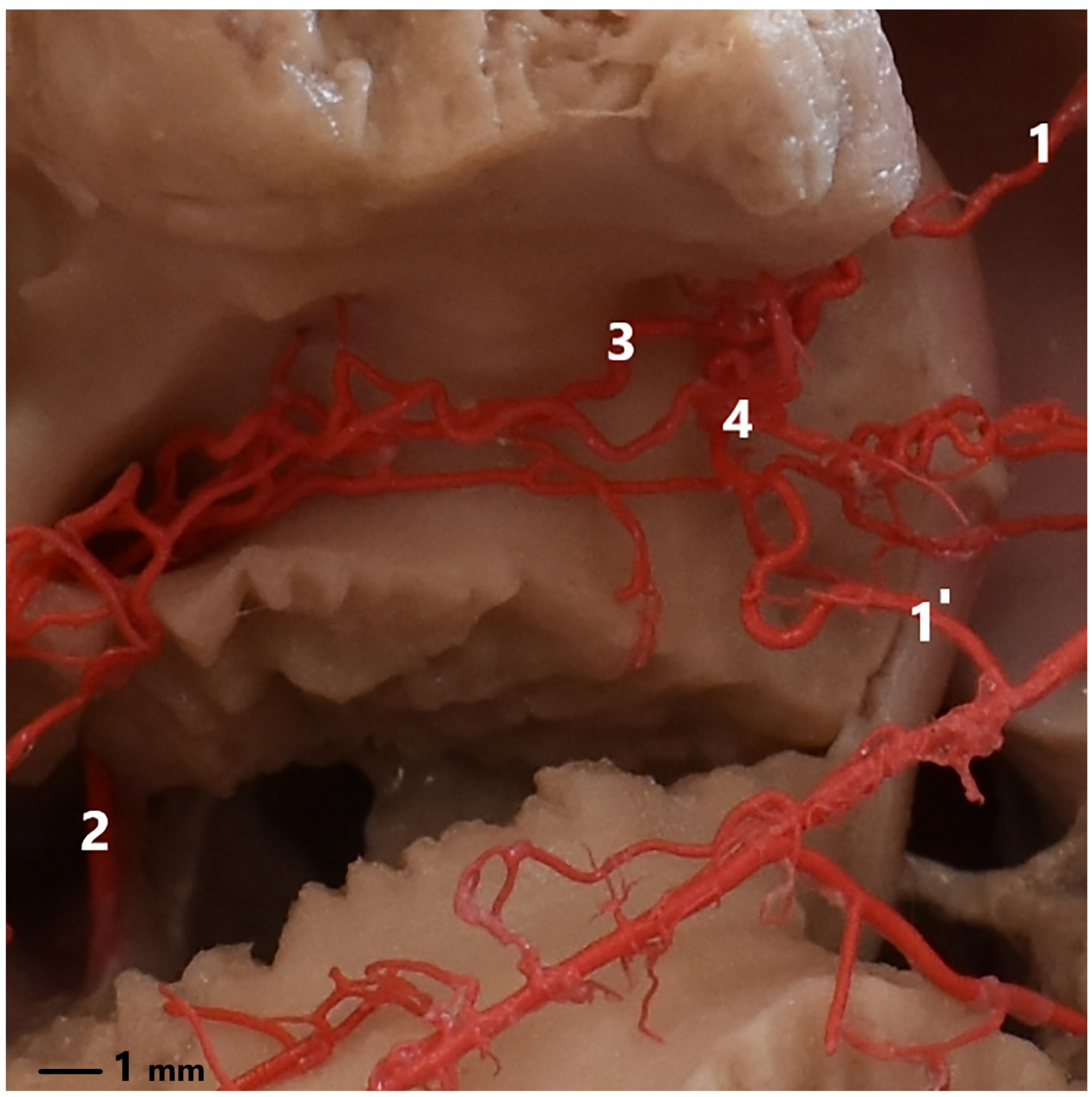




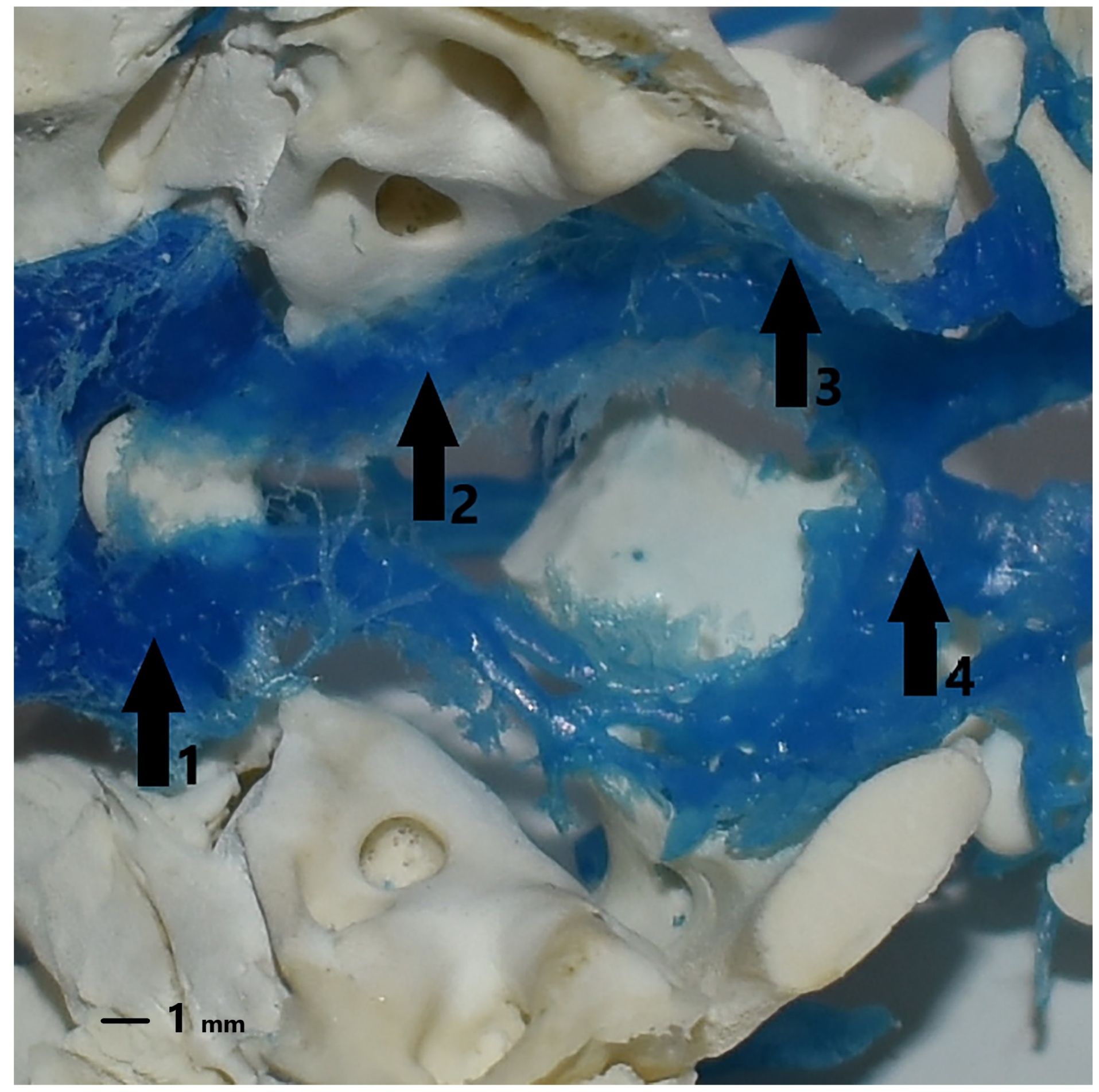




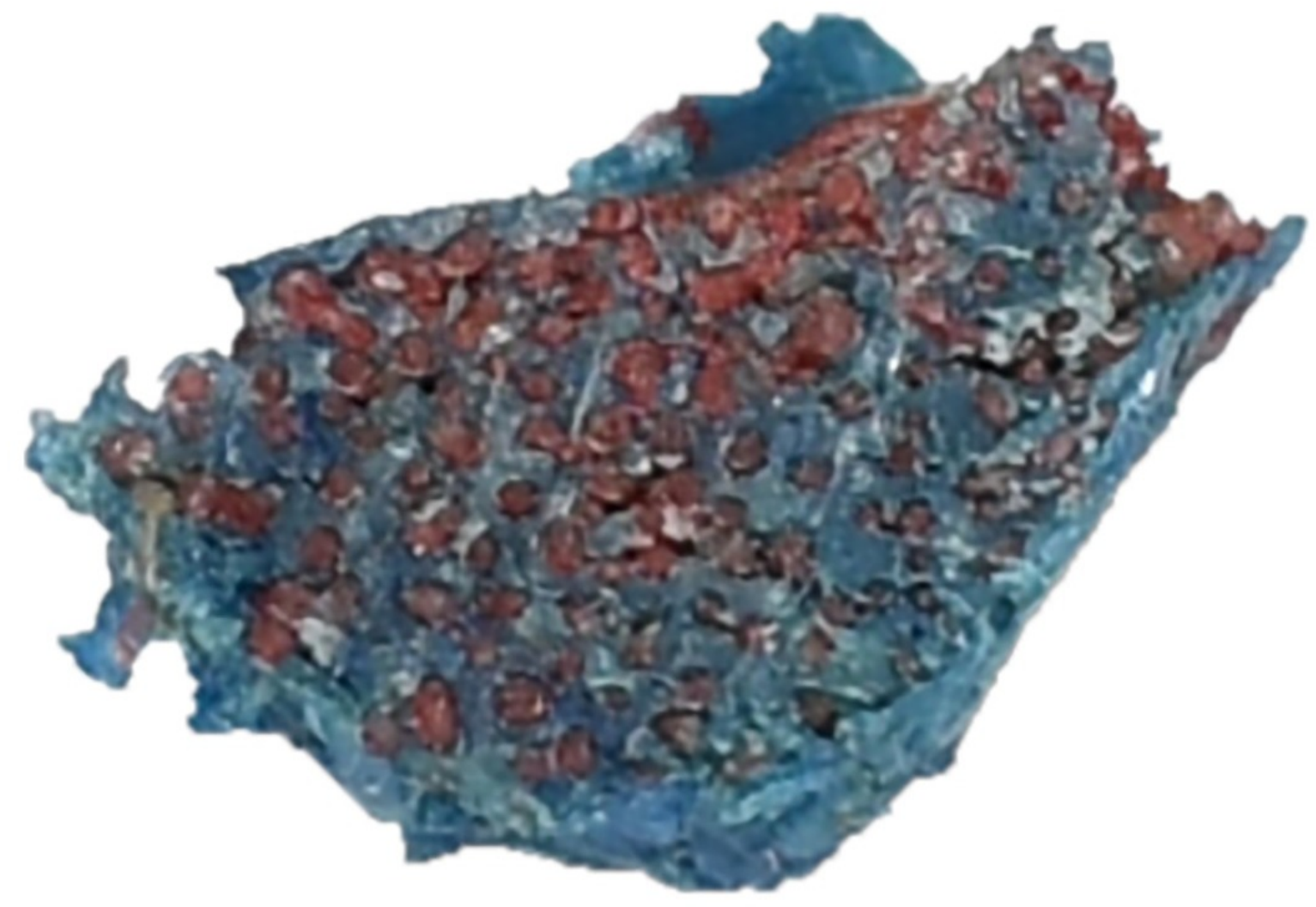




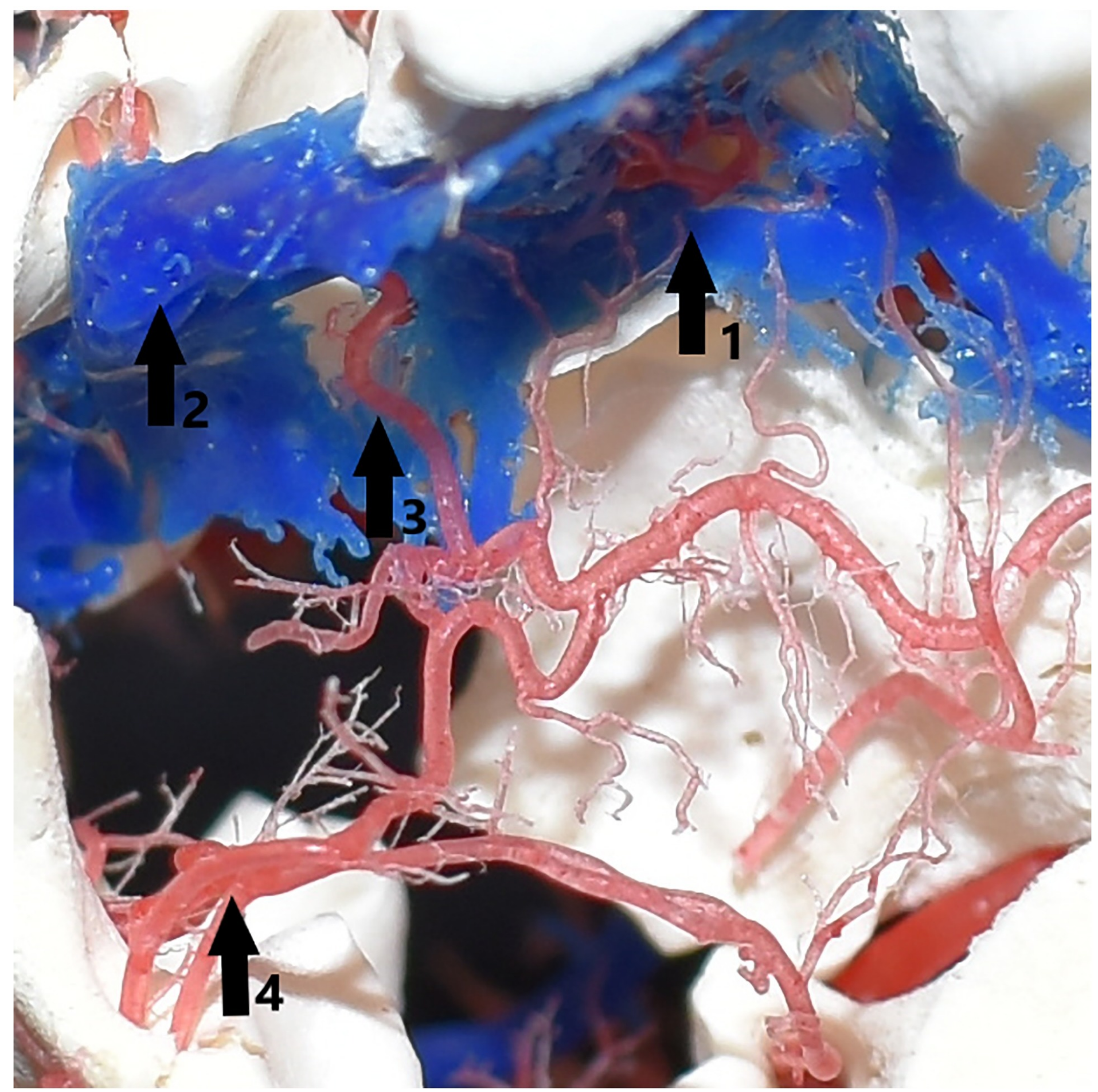

